\title{
US heads for trouble on reactors for China
}

Washington

THE United States is inching closer towards crowning its improving scientific and technological links with China by selling it two pressurized water reactors in the thousandmegawatt range. Senior administration officials do not expect President Reagan to clinch the deal during his visit to China this month, but they maintain that the Chinese, by making significant new commitments to the principle of non-proliferation, have removed the most serious remaining obstacle.

The US-China agreement on science and technology, signed by President Carter in 1979, has become increasingly important for the Chinese. Extended last January for another five years, it is now the most extensive intergovernmental science and technology programme involving the United States. More than 10,000 Chinese citizens are now studying or undertaking research in the United States, about half sponsored by the Chinese government; the rest study under private auspices.

An indication of the importance the Chinese attach to the agreement is their reluctance to allow disagreements with the United States, notably over Taiwan, to interfere with scientific and technical exchanges. China's biggest complaint, the imposition of stringent controls in the export of security-related US technology, has been substantially met. Last November the United States transferred China from the "special export" category to the category of "friendly but not allied" nations.

Until recently, China's failure to sign the Non-Proliferation Treaty (NPT) appeared to have placed an insuperable obstacle in the path of a nuclear agreement between the two countries. In January, however, China joined the International Atomic Energy Agency (IAEA) and Premier Zhao Ziyang, visiting Washington in the same month, emphasized China's wish to prevent proliferation.

Both the Reagan Administration and the US nuclear industry are eager to press ahead with the reactor deal. China has no operational nuclear power plants at present, and its intention to build up to ten reactors makes it the only promising foreign market, apart perhaps from Egypt, for US reactors. US manufacturers have meanwhile been prevented, while the agreement has been under discussion, from bidding for a share of the work on China's two-reactor project at Guan Dong. Their British and French competitors have not been so constrained, while Japan is supplying the pressure vessel for an indigenous 300-megawatt reactor under construction near Shanghai.

Congress may yet stand in the way of an agreement, however. Because China already possesses nuclear weapons, its failure to sign the treaty puts no legal obstacles in the way of a sale. But the US Atomic Energy Act, as amended by the 1978 Non-Proliferation Act, contains several provisions that could offend Chinese national sensibilities and enable those in Congress who suspect China of helping Pakistan develop a nuclear weapons programme to block the agreement. The real stumbling block is a provision that allows the United States to veto the reprocessing of Chinese nuclear fuel used in a reactor supplied from the United States. Countries already thus affected complain that the provision is cumbersome, disrupting their nuclear power planning. Japan, for example, has routinely to seek US permission to ship spent fuel to France and Britain for reprocessing.

Privately, administration and congres- sional officials concede that for a nuclear power such as China, US exertions to stress the importance of non-proliferation are symbolic rather than substantive. US policy, however, is to win international support for the Non-Proliferation Treaty by managing its nuclear relations with nuclear and non-nuclear powers on an equal basis.

In some cases, that has proved difficult. The Federation of American Scientists (FAS), for example, is concerned about the State Department's failure to enforce several agreements between the United States and the European Atomic Energy Community (Euratom) which, it believes, obliges the United States to prevent France from using its new Superphénix breeder reactor for nuclear weapons purposes. Up to 30 per cent of the plutonium to be used in the initial core of Superphenix was separated from spent-fuel originating in the United States. FAS, and several congressmen, believe the United States is legally obliged to see that none of that plutonium is used for military purposes.

France, however, refuses to identify which nuclear reactors contribute to its weapons capabilities. An attempt by the US State Department to meddle with the running of the proud Superphenix project could hardly fail to arouse some fierce Gallic hauteur.

US nuclear power

\section{Management blamed for failure}

\section{Washington}

A MARATHON research study just completed by the Nuclear Regulatory Commission (NRC) has concluded that poor management by power companies and their contractors - not the complexity of NRC regulations - is the underlying cause of the chronic technical deficiencies of many new US reactors. The report, one of the most outspoken ever issued by NRC, says many first-time reactor builders have embraced nuclear technology with a "false sense of security" engendered by previous successes with fossil fuel plants.

NRC, which undertook the study at the insistence of Congress, looked in detail at four reactor projects (Marble Hill, Zimmer, South Texas and Diablo Canyon) that have been plagued by difficulties. In most cases, it concluded, the difficulties were due to inadequate management, not to poor craftsmanship by builders and technicians. In almost all cases, the power companies' experience had been limited to construction of fossil fuel plants, and managers approached the building of reactors without appreciating the technological challenges. NRC reports that one (unidentified) chief executive described his utility's first planned nuclear plant as "just another tea kettle"'.

This overconfidence, the commission found, tended to result in understaffing and the selection of contractors with limited experience of building nuclear plants. Often, power companies used the same contractor to build the plant and to monitor its progress. In some cases, the report says, nobody was managing the project; "the project had inertia but no guidance or direction". Previous nuclear experience, NRC maintains, appears to be the single most important advantage of companies which had been able to build reactors with relatively little difficulty.

The commission concedes that it must share some of the blame for having granted construction permits to power companies that would not have received them in today's stricter regulatory environment. The study recommends that future applicants for construction permits will have to prove their overall managerial competence, both before receiving a permit and at two-year intervals thereafter. NRC is considering setting up a new advisory comittee to judge the managerial ability of applicants.

The commission may also adopt a recommendation in the report to set up a system of independent inspectors to audit the progress of reactor projects every two years. NRC would establish guidelines for the audits, but the inspectors would be independent third parties whose job would be to ensure that plants were being built according to their design and licensing requirements.
Peter David 